\title{
INFLUENCE OF DIFFERENT FOOD SOURCES ON GROWTH AND REPRODUCTION PERFORMANCE OF COMPOSTING EPIGEICS: EUDRILUS EUGENIAE, PERIONYX EXCAVATUS AND PERIONYX SANSIBARICUS
}

\author{
S. SUTHAR \\ Department of Zoology, J.N.V. University, Jodhpur - 342001, INDIA \\ Environment Biology lab, Department of Zoology, M. D. (PG) College, \\ Sri Ganganagar 335 001, India \\ (phone: + 91-0154-2470452 (R), fax: +91-0154-2475960) \\ e-mail: sutharss_soilbiology@yahoo.co.in, sutharss_biosoil@rediffmail.com \\ (Received $9^{\text {th }}$ January 2006; accepted $13^{\text {th }}$ May 2007)
}

\begin{abstract}
The impact of organic material quality on biomass production and reproduction potential of commercial composting earthworm species: Eudrilus eugeniae, Perionyx excavatus and Perionyx sansibaricus were studied, by using three different type of culture material namely Jbs: (Jowar straw (Sorghum vulgare) + bajra straw (Pennisetum typhoides) + sheep manure) (1:1:2), fym (farmyard manure), and $\mathrm{Kw}+\mathrm{Ll}$ (Kitchen waste + leaf litter of Magifera indica) (1:1), under laboratory conditions for 150 days. The above substrate or culture materials have different palatability, particle size and physiochemical composition. Kitchen waste $(\mathrm{C}-$ to- $\mathrm{N}=26.7)$ as well as farmyard manure $(\mathrm{C}-\mathrm{to}-\mathrm{N}=27.4)$ is a high quality material with fast decomposition rates, while crop residues are low quality materials with slow decomposition rates $(\mathrm{C}$-to- $\mathrm{N}=45.6)$. All the three studied earthworm species showed maximum biomass production rate in $\mathrm{Kw}+\mathrm{Ll}$ culture $\left(\right.$ E. eugeniae $=9.80 \pm 0.01 \mathrm{mg} \mathrm{worm}^{-1}$ day $^{-1}, P$. excavatus $=$ $3.75 \pm 0.01 \mathrm{mg}$ worm ${ }^{-1} \mathrm{day}^{-1}$, and $P$. sansibaricus $\left.=3.77 \mathrm{mg} \mathrm{worm}^{-1} \mathrm{day}^{-1}\right)$. Individual cocoon production rate varied drastically, and maximum value $\left(\right.$ worm $^{-1}$ week $\left.^{-1}\right)$ of it was observed in $\mathrm{Kw}+\mathrm{Ll}$ for $E$. eugeniae $(1.88 \pm 0.15)$ and $P$. sansibaricus $(1.77 \pm 0.14)$, while $P$. excavatus showed maximum cocoon production rate in Fym $(1.79 \pm 0.17)$. The hatchling success of cocoons obtained from different beddings was also observed and cocoon obtained from $\mathrm{Kw}+\mathrm{Ll}$ culture exhibited maximum hatchling success $(\%)$ in all the three species studied. The cocoons of both E. eugeniae and P. sansibaricus, obtained from Fym culture showed the highest number of hatchlings $\left(\right.$ cocoon $\left.^{-1}\right)$ i.e. $1.59 \pm 0.04$ and $1.81 \pm 0.10$, respectively, whereas cocoons of $P$. excavatus showed the highest hatchling number $(1.77 \pm 0.06)$ in $\mathrm{Kw}+\mathrm{Ll}$. In this present study, there was a consistent trend of decreasing individual biomass as well as cocoon production rate, followed by their peak values with ageing of the culture materials. The relationship between different earthworm parameters and $\mathrm{N}$-content or $\mathrm{C}$-to- $\mathrm{N}$ of culture material was also evaluated. The biomass production rate and hatching success in all the three species studied showed direct correlation $(\mathrm{p}<0.05)$ with $\mathrm{N}$-content of the culture material. However, beddings' $\mathrm{N}$-content did not affect the individual cocoon production rate, except to $P$. sansibaricus $(\mathrm{r}=0.987, \mathrm{P}<0.001)$. The number of hatchlings per cocoon for $P$. sansibaricus, showed good correlation $(\mathrm{r}=0.935 \mathrm{p}<0.01)$ with $\mathrm{N}$-content of organic material used for worm culture. Results clearly show a possible relation between hatchling success/number of hatchlings per cocoon, and chemistry of culture substrate.
\end{abstract}

Keywords: organic waste, vermiculture, Eudrilus eugeniae, Perionyx excavatus, Perionyx sansibaricus, Cocoon, Hatchlings success, Hatchling number

\section{Introduction}

Vermicomposting is a biooxidation and stabilization of organic material involving the joint action of earthworms and microorganisms [1], where negligible organic waste resources are converted into nutrient rich plant growth media i.e. vermicompost. Studies reveal that epigeics seem well fitted for such kind of operations, because of their surface activity, their ability to colonize organic material quickly, and in the process to convert 
it into useful compost and their ability to minimize malodour formation. However, involvement of earthworms in composting process decreases the time of stabilization of the waste and produces an organic pool with energy reserves as vermicompost [38]. The composting biology and ecology of earthworms in waste resources are controlled by several abiotic and biotic factors: temperature, moisture, $\mathrm{pH}$, substrate, feed and its palatability, particle size, earthworm density and fecundity, which directly or indirectly influence the composting potential of the composting species.

Several earthworm species e.g. Eisenia fetida, Eisenia andrei, Eudrilus eugeniae, Perionyx excavatus have been identified as potential candidates for managing organic waste resources. World-wide spread E. fetida was and still remains a favoured earthworm species for vermicomposting operations due to their wide range of tolerance for environmental variables. The growth patterns $E$. fetida in number of different organic waste resources have been investigated by various authors in laboratory culture $[9,12,18,17]$. However, in tropical and sub-tropical conditions earthworm: P. excavatus, $P$. sansibaricus, and E. eugeniae appeared as best vermicomposting species. The life cycle parameters of above tropical species has been investigated in respect to their environmental requirement like temperature [37], moisture [13], fecundity and density pressure [16], $\mathrm{pH}$ [31], but influence of culture material or substrate quality on their life cycle parameters is less considered. Although, animal dung is recognized as a suitable earthworm culture media, but other organic waste material from agriculture and industry have also proved successful. The chemical structure of given culture media for large scale vermiculture practices is always important. Besides to high concentrations of nutrient in plant origin wastes, some secondary metabolites e.g. polyphenols are also important, which directly or indirectly influence the composting potential as well as growth patterns of given composting species during vermicomposting practices. The impact of such kind of wastes on life cycle parameters of composting worms must be of a research priority.

The aims of this study were three-fold. First, to establish whether types of substrate or feeding material effect the biomass and cocoon production patterns in composting earthworm species: Eudrilus eugeniae Kinberg, Perionyx excavatus (Perrier, 1872) and Perionyx sansibaricus (Perrier, 1872), which are very popular for commercial vermitechology programs in many part of the world. Second, to confirm the fact that earthworm shows species-specific sensitivity for C-to-N ratio or for other chemical substances presented in the substrates [27]. Does all earthworm species showed specific behaviour for physio-chemical quality of feeding stuff, or they are more sensitive for Ncontent or some other content of it? Third, to investigate, by means of a cocoon hatchling experiments, whether the quality of organic material is important factor for production of viable cocoons and for hatchling numbers per cocoon. Knowledge about the effect of feed quality on hatchling success and number of hatchlings per cocoon is very scared in scientific literature. In present study three different types of culture materials: crop residues with animal dung, farm yard manure, and kitchen waste with leaf litter were selected for experimentation, mainly due to their different chemical, microbial and physical nature. 


\section{Review of literature}

The biology of composting earthworms had been investigated in terms of their certain fundamental requirements, for instance the temperature [17,23,28,37], $\mathrm{pH}$ [17,31], density or stocking rate [16,30], substrate [4,7], and moisture content of the substrate $[13,29]$. The effect of bedding substrate on biological parameters such as biomass production, cocoon numbers, hatchling success in popular composting earthworms is still unanswered. A review by Lowe and Butt [24] demonstrated the recent research on the development of earthworm culture techniques for temperate, soil dwelling (anecic and endogeic) species: Allolobophora chlorotica, Aporrectodea caliginosa, Aporrectodea longa and Lumbricus terrestris. In this paper they summarized the optimum requirements of these species for laboratory-based culture. Nevertheless, for commercial based vermicomposting practices much of the research have been focused on Eisenia fetida [8,14,18,22,25,36]; Lumbricus rubellus [5,19] and Dendrobaena veneta [10,20,21]. Some tropical composting earthworms namely Eudrilus eugeniae, Perionyx excavatus and Perionyx sansibaricus had been getting much attention among the commercial worm growers in both tropical and sub tropical countries. Unfortunately, little is known about their nutrition for mass rearing. However, among the different variables necessary for raising earthworms, it seems that the type of feeding material or substrate is most important. According to Edwards [9] the type, quality and quantity of the organic wastes were very important to determining the rates of growth of earthworms. In general, for large-scale vermiculture practices the knowledge of biological requirement of candidate species must be pre-determined and their optimum requirement concerning nutritional factors might be an active field of research in earthworm biotechnology [3, 24]. However, different earthworm species are impacted differently by nutritional status for a specific earthworm species [33, 34], and a specific feed mixture [35]. Recently Singh et al. [31] demonstrated the effect of initial substrate $\mathrm{pH}$ on vermicomposting potential of $P$. excavatus. They concluded that the earthworm species $P$. excavatus performs well in a wide range of substrate $\mathrm{pH}$, but neutral initial $\mathrm{pH}$ of substrate was found to be suitable for stabilization of waste with minimal processing time. It is well understand that the quality and amount of food material influences not only the size of population but also the species present and their rate of growth and cocoon production $[12,23,35]$. However, earthworm biomass and cocoon production rate can acts useful biomarkers to measure the efficiency of earthworm in vermiculture operations. Hendricksen [15] suggested that C-to-N ratio and particularly polyphenols concentration are the most important factor determining litter palatability in detrivorus earthworms. It is very important to evaluate the influence of feed stocks on life cycle of tropical earthworms.

\section{Materials and methods}

\section{Preparation of feeding material}

Three different type of feeding materials namely Jbs (Jowar straw + bajra straw + sheep manure) (1:1:2), fym (farmyard manure) and $\mathrm{Kw}+\mathrm{Ll}$ (Kitchen waste + leaf litter of Magifera indica) (1:1) was used during present study. Jbs was prepared from the dry straw of Sorghum vulgare (Jowar straw); Pennisetum typhoides (bajara straw) and sheep 
manure, mixed in 1:1:2 ratios. All plant materials were obtained from a local agriculture field, Jhalamand village, Jodhpur, India. Urine free sheep manure was obtained from a local sheep farm and 1-week-old farmyard manure was collected from Jhanwarangarh Agriculture Farm, Kakani Road, Jodhpur. Kitchen waste was collected from P.G. Boys Hostel, New Campus, J.N.V. University, Jodhpur.

All the three prepared culture beddings were kept for prior microbial composting and thermostabilization for 15 days in large closed container with small drain holes drilled in the bottoms. The moisture content of the beddings was maintained $60-70 \%$ by sprinkling water regularly.

\section{Earthworm culture}

$100 \mathrm{gm}$ of pre-composted organic material was taken in plastic containers $(20 \mathrm{~cm}$ height, $28 \mathrm{~cm}$ diameter) with plastic lids pierced by aeration holes. Five juveniles (one week old) of Eudrilus eugeniae, Perionyx excavatus and Perionyx sansibaricus, each in the range of $9.9-14.6 \mathrm{mg}$ fresh weight, were collected from stock culture in laboratory. These juveniles were pre weighed and inoculated in experimental containers. Each experiment was replicated five times. The earthworm were counted and weighed every week for 22 weeks. The total number of cocoons produced in different experimental containers was counted during each week.

For hatchling experiment fresh cocoon of all the three species were collected from each experimental bedding type. For this ten cocoon of each species were placed in Petri dished, containing the parental bedding material (material where cocoons were laid down originally). Petri plates of each culture type were replicated five times for each earthworm species studied. Petri plates were observed regularly for hatchling of cocoons. Simultaneously number of hatchlings produced from each cocoon was also calculated. The hatchling success was calculated in percent by counting total number of hatched cocoons in each Petri plate. Newly emerged earthworms (juveniles) were transferred in separate containers contained the same parental material and the total earthworm production was calculated at the end of the experiment. The experimental containers were incubated in dark and humid palace at room temperature $(28.9 \pm$ $\left.0.53^{\circ} \mathrm{C}\right)$.

\section{Chemical analysis}

The organic bedding material was analyzed for organic $\mathrm{C}$, total $\mathrm{N}$, total phosphorus, potassium, C-to-N ratio (Table 1). Organic $\mathrm{C}$ was determined by Walkley - Black method. Nitrogen was determined by following the microkjeldhal method. Phosphorous was estimated by using Tecator model 5012 auto analyzer. The amount of exchangeable potassium was analyzed at Perkin Elmer model 3110 double beam atomic absorption spectrophotometer.

Table 1. Chemical properties of different culture materials.

\begin{tabular}{cccccc}
\hline $\begin{array}{c}\text { Culture } \\
\text { Material }\end{array}$ & $\begin{array}{c}\text { Carbon } \\
\left(\mathrm{g} \mathrm{kg}^{-1}\right)\end{array}$ & $\begin{array}{c}\text { Nitrogen } \\
\left(\mathrm{g} \mathrm{kg}^{-1}\right)\end{array}$ & $\begin{array}{c}\text { Phosphorous } \\
\left(\mathrm{g} \mathrm{kg}^{-1}\right)\end{array}$ & $\begin{array}{c}\text { Potassium } \\
\left(\mathrm{g} \mathrm{kg}^{-1}\right)\end{array}$ & $\begin{array}{c}\mathrm{C} \text { to N } \\
\text { ratio }\end{array}$ \\
\hline $\mathrm{Jbs}$ & $477.14 \pm 0.05$ & $10.44 \pm 0.05$ & $4.05 \pm 0.01$ & $4.18 \pm 0.02$ & $45.57 \pm 0.16$ \\
Fym & $348.56 \pm 0.08$ & $12.62 \pm 0.22$ & $6.73 \pm 0.04$ & $9.86 \pm 0.03$ & $27.44 \pm 0.56$ \\
$\mathrm{Kw}+\mathrm{Ll}$ & $389.62 \pm 0.24$ & $15.56 \pm 0.03$ & $5.76 \pm 0.10$ & $12.42 \pm 0.03$ & $26.76 \pm 0.04$ \\
\hline
\end{tabular}

APPLIED ECOLOGY AND ENVIRONMENTAL RESEARCH 5(2): 79-92. http://www.ecology.uni-corvinus.hu • ISSN 15891623

(c) 2007, Penkala Bt., Budapest, Hungary 


\section{Statistical analysis}

Data were subjected for analysis of variance (ANOVA) followed by Duncan's multiple-ranged tests to differentiate the statistical difference between results of earthworm growth, cocoon production rate, hatchling success, number of hatchlings $\operatorname{cocoon}^{-1}$, and total earthworm population in different culture material. Pearson's correlation coefficient was also calculated between chemical parameters of culture material and different parameters of earthworms.

\section{Results}

\section{Earthworm growth}

The earthworm biomass production in different feeding mixture is illustrated in (Fig $1(a, b, c)$ ). Statistically both feed mixtures (or culture material) and species type showed significant $(\mathrm{P}<0.01)$ difference in biomass production patterns (Table 2$)$.

Table 2. ANOVA table

\begin{tabular}{cccc}
\hline & $d f^{b}$ & $\mathrm{~F}$ & $\mathrm{P}$ \\
\hline Cocoon production & & & \\
$\quad$ Species & 2 & 10.61 & $<0.001$ \\
Feeding material & 2 & 77.98 & $<0.001$ \\
Species $\times$ Feeding material & 4 & 24.81 & $<0.001$ \\
Biomass production & & & \\
$\quad$ Species & 2 & 19378.58 & $<0.001$ \\
Feeding material & 2 & 1615.55 & $<0.001$ \\
Species $\times$ Feeding material & 4 & 326.5936 & $<0.001$ \\
Hatchling success & & & \\
$\quad$ Species & 2 & 2.781372 & 0.088 \\
Feeding material & 2 & 34.13211 & $<0.001$ \\
Species $\times$ Feeding material & 4 & 2.237684 & 0.105 \\
Hatchlings cocoon & & & \\
Species & 2 & 0.725048 & 0.497 \\
Feeding material & 2 & 8.986634 & 0.001 \\
Species $\times$ Feeding material & 4 & 10.97509 & $<0.001$ \\
\hline
\end{tabular}

Table 3. Earthworm biomass ( $m g$ ) (mean $\pm S E m ; n=5)$ production in different culture material

\begin{tabular}{cccccccccc}
\hline $\begin{array}{c}\text { Culture } \\
\text { Material }\end{array}$ & \multicolumn{3}{c}{ Eudrilus eugeniae } & \multicolumn{3}{c}{ Perionyx excavatus } & \multicolumn{2}{c}{ Perionyx sansibaricus } \\
\cline { 2 - 10 } & $\begin{array}{c}\text { At } \\
\text { start }\end{array}$ & $\begin{array}{c}\text { At } \\
\text { end }\end{array}$ & $\begin{array}{c}\text { Growth } \\
\text { Rate* }^{*}\end{array}$ & $\begin{array}{c}\text { At } \\
\text { start }\end{array}$ & $\begin{array}{c}\text { At } \\
\text { end }\end{array}$ & $\begin{array}{c}\text { Growth } \\
\text { Rate* }^{*}\end{array}$ & $\begin{array}{c}\text { At } \\
\text { start }\end{array}$ & $\begin{array}{c}\text { At } \\
\text { end }\end{array}$ & $\begin{array}{c}\text { Growth } \\
\text { Rate* }^{*}\end{array}$ \\
\hline $\mathrm{Jbs}$ & $14.6 \pm$ & 1129.5 & $7.24 \pm$ & $9.9 \pm$ & $358.4 \pm$ & $2.26 \pm$ & $10.4 \pm$ & 476.8 & $3.03 \pm$ \\
& 0.16 & $\pm 3.12^{\mathrm{a}}$ & $0.02^{\mathrm{a}}$ & 0.22 & $1.81^{\mathrm{a}}$ & $0.02^{\mathrm{a}}$ & 0.05 & $\pm 2.36^{\mathrm{b}}$ & $0.01^{\mathrm{b}}$ \\
$\mathrm{Fym}$ & $14.0 \pm$ & 1151.4 & $7.39 \pm$ & $10.3 \pm$ & $539.7 \pm$ & $3.44 \pm$ & $9.8 \pm$ & 445.5 & $2.83 \pm$ \\
& 0.12 & $\pm 3.28^{\mathrm{b}}$ & $0.02^{\mathrm{a}}$ & 0.09 & $1.56^{\mathrm{b}}$ & $0.03^{\mathrm{b}}$ & 0.09 & $\pm 2.37^{\mathrm{a}}$ & $0.03^{\mathrm{a}}$ \\
$\mathrm{Kw}+\mathrm{Ll}$ & $14.1 \pm$ & 1522.9 & $9.80 \pm$ & $10.2 \pm$ & $587.3 \pm$ & $3.75 \pm$ & $9.5 \pm$ & 589.6 & $3.77 \pm$ \\
& 0.05 & $\pm 1.10^{\mathrm{c}}$ & $0.01^{\mathrm{b}}$ & 0.05 & $4.46^{\mathrm{c}}$ & $0.01^{\mathrm{c}}$ & 0.12 & $\pm 3.63^{\mathrm{c}}$ & $0.02^{\mathrm{c}}$ \\
\hline
\end{tabular}

* $\left(\mathrm{mg}\right.$ worm $^{-1}$ day $\left.^{-1}\right)$

The mean values followed by different letters are statistically different (ANOVA, Duncan's multipleranged test; $\mathrm{p}<0.05$ ) 

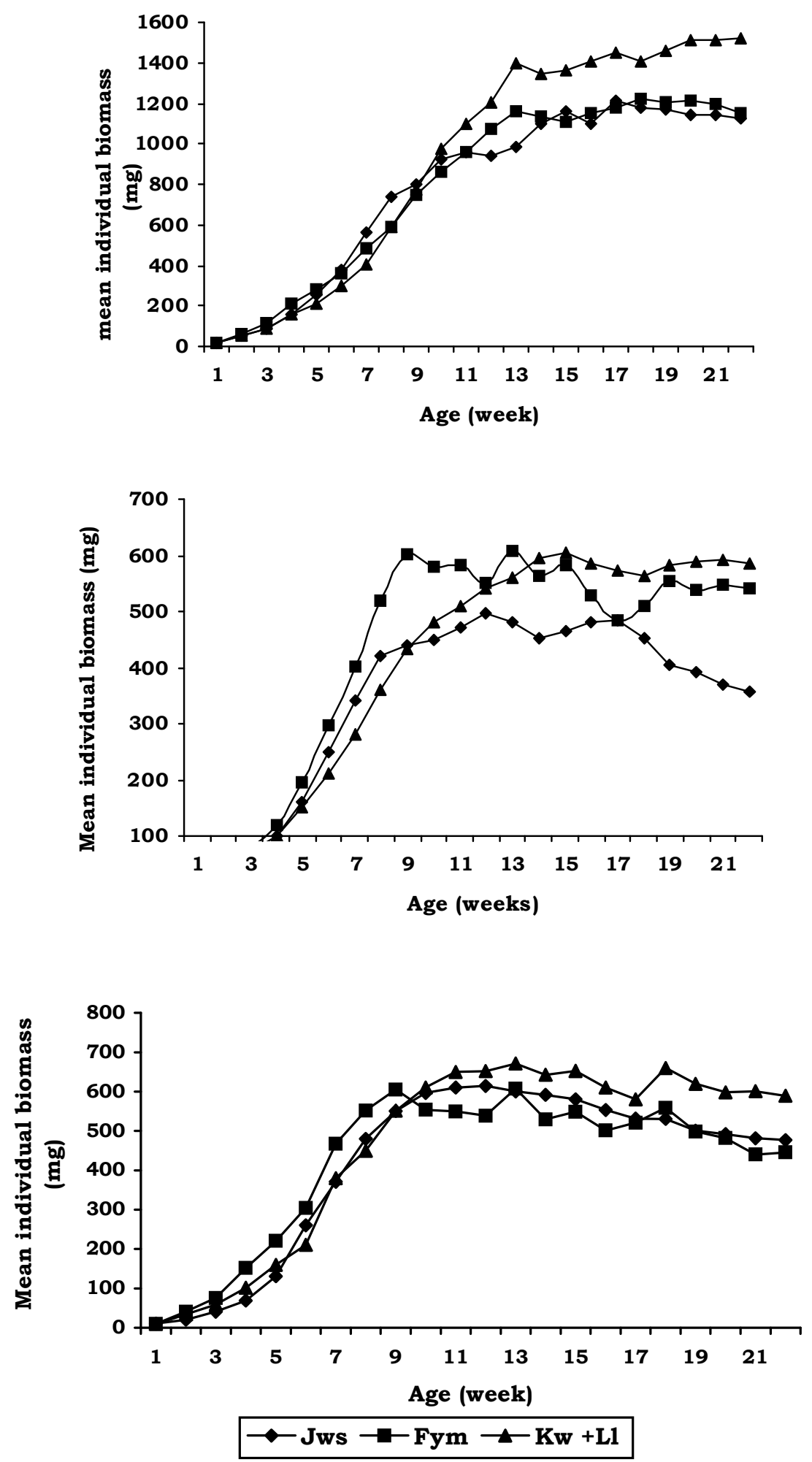

Figure 1. The growth of E. eugeniae (a), P. excavatus (b) and P. sansibaricus (c) in different waste materials. 
E. eugeniae showed maximum mean individual biomass $(1522.9 \pm 1.10 \mathrm{mg})$ on $\mathrm{Kw}$ $+\mathrm{Ll}$ followed by Fym, and Jbs culture. The maximum individual biomass of $E$. eugeniae on $\mathrm{Kw}+\mathrm{Ll}$ was 34.8 and $32.3 \%$ higher than $\mathrm{Jbs}$ and Fym culture, respectively (Table 3). In E. eugeniae maximum mean individual biomass was reached after 17 week (1210.6 $\pm 1.01 \mathrm{mg})$ on Jbs, after 18 week (1220.4 $\pm 4.15 \mathrm{mg})$ on Fym, and after 22 week $(1522.9 \pm 1.10 \mathrm{mg})$ on $\mathrm{Kw}+\mathrm{Ll}$ (Fig. 1 (a)). At the end of experiment the maximum mean individual biomass in $P$. excavatus was registered with $\mathrm{Kw}+\mathrm{Ll}(587.3$ $\pm 4.46 \mathrm{mg}$ ) followed by fym, and Jbs (Table 3). The maximum mean biomass of $P$. excavatus was $63.9 \%$ and $8.8 \%$ higher than the individual biomass on Jbs and fym, respectively. $P$. excavatus achieves its' peak of individual biomass after 12 week, 13 week, and 15 week on Jbs $(495.7 \pm 4.67 \mathrm{mg})$, Fym $(608.6 \pm 2.94 \mathrm{mg})$, and $\mathrm{Kw}+\mathrm{Ll}$ $(603.3 \pm 3.97 \mathrm{mg})$, respectively $($ Fig. 1(b)). In both Fym and $\mathrm{Kw}+\mathrm{Ll}$ cultures, $P$. excavatus showed excellent biomass increase up to achieving the peak, afterward a clear stabilization was observed, while in Jbs a drastic decline in biomass was noted up to end of the experiment. $P$. sansibaricus showed maximum mean individual biomass on $\mathrm{Kw}+$ $\mathrm{Ll}(589.6 \pm 3.63 \mathrm{mg})$ followed by Jbs and Fym at the end of the experiment (Table 3). The maximum mean biomass of $P$. sansibaricus was 23.7 and $32.3 \%$ higher than Jbs and Fym, respectively. P. sansibaricus showed more or less stabilized pattern for biomass production after achieving peak values of it in Fym and $\mathrm{Kw}+\mathrm{Ll}$, but on Jbs a gradual linear decline was noted up to end of the experiment (Fig. 1 (c)).

\section{Cocoon production}

The cocoon production patterns of all the three studied species in different culture material have been illustrated in (Fig. $2(a, b, c))$. There was consistent pattern of influence of the culture material $(\mathrm{P}<0.001)$, as well as species type on total cocoon production $(\mathrm{P}<0.001)$ (Table 2). Earthworm in most of the culture beddings started to produce cocoons after 7-8 weeks. In E. eugeniae maximum cocoon numbers (worm ${ }^{-1}$ ) and reproduction rate (cocoon worm ${ }^{-1}$ week $^{-1}$ ) was recorded on $\mathrm{Kw}+\mathrm{Ll}$ culture $(150.67$ \pm 5.51 and $1.88 \pm 0.15$, respectively) followed by Fym and Jbs (Table 4). The highest cocoon number in $\mathrm{Kw}+\mathrm{Ll}$ was, respectively 54.3 and $18.3 \%$ higher from that of Jbs and Fym culture. The peak value of cocoon production rate (cocoon worm ${ }^{-1}$ week $^{-1}$ ) in E. eugeniae was recorded on $\mathrm{Jbs}, \mathrm{Fym}$, and $\mathrm{Kw}+\mathrm{Ll}$ in $18^{\text {th }}$ week $(1.87 \pm 0.20), 18^{\text {th }}$ week $(2.53 \pm 0.22)$, and $16^{\text {th }}$ week $(2.80 \pm 0.25)$ of culture, respectively (Fig. $\left.2(a)\right)$.

$P$. excavatus, exhibited maximum cocoon numbers and cocoon production rate on Fym $(143.0 \pm 4.33$ and $1.79 \pm 0.17$, respectively) followed by $\mathrm{Jbs}$, and $\mathrm{Kw}+\mathrm{Ll}$ (Table 4). The maximum cocoon production on Fym culture was 34.5 and $37.9 \%$, higher than that of Jbs and Fym, respectively. Similarly, P. excavatus exhibited peak value of reproduction rate in Jbs (2.27 \pm 0.20$)$, Fym $(2.67 \pm 0.24)$, and $\mathrm{Kw}+\mathrm{Ll}(2.07 \pm$ 0.14 ) in $18^{\text {th }}, 16^{\text {th }}$ and $19^{\text {th }}$ week of culture (Fig. $2(b)$ ). The maximum number of cocoons and individual reproduction rate in $P$. sansibaricus was recorded in $\mathrm{Kw}+\mathrm{Ll}$ (141.67 \pm 2.33 and $1.77 \pm 0.14$, respectively) followed by Fym and Jbs culture. The greater cocoon numbers on $\mathrm{Kw}+\mathrm{Ll}$ was 108.3 and $22.8 \%$ higher than that of Jbs and Fym culture, respectively. $P$. sansibaricus showed its' peak reproduction rate on Jbs $(1.33 \pm 0.10)$, Fym $(2.27 \pm 0.05)$, and $\mathrm{Kw}+\mathrm{Ll}(2.67 \pm 0.05)$ in $16^{\text {th }} \& 19^{\text {th }}, 17^{\text {th }}$ and $18^{\text {th }}$ week of culture (Fig. 2 (c)). However, there was a tendency for the mean cocoon production rate to decrease relatively to the ageing of the bedding materials. 

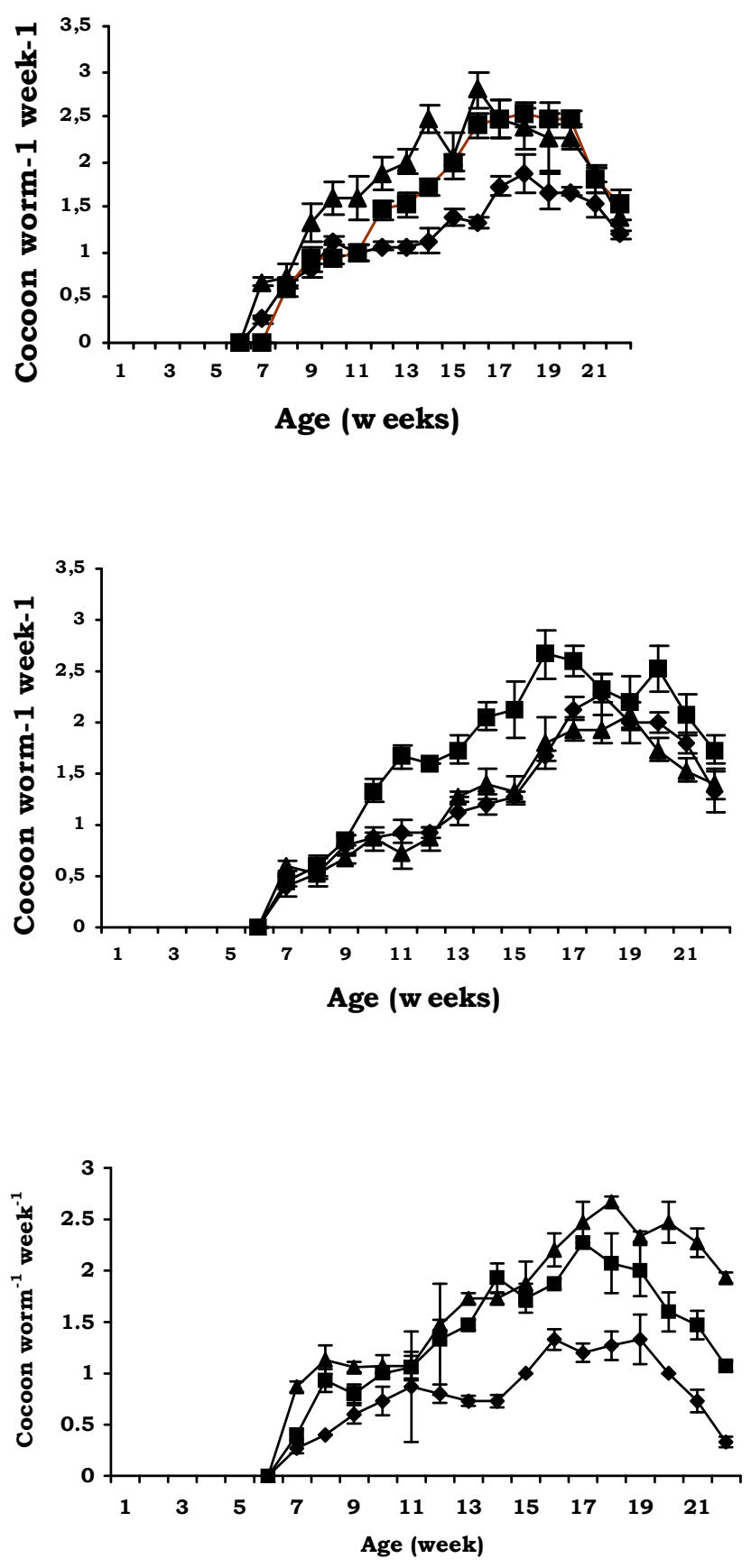

$\leadsto-\mathrm{Jws} \rightarrow \mathrm{Fym} \rightarrow \mathrm{Kw}+\mathrm{Ll}$

Figure 2. The cocoon production by E. eugeniae (a), P. excavatus (b) and P. sansibaricus (c) in different waste materials. 
Table 4. Cocoon (mean \pm SEm; $n=5$ ) production in different culture material

\begin{tabular}{|c|c|c|c|c|c|c|c|c|c|}
\hline \multirow{2}{*}{$\begin{array}{c}\text { Culture } \\
\text { Material }\end{array}$} & \multicolumn{3}{|c|}{ Eudrilus eugeniae } & \multicolumn{3}{|c|}{ Perionyx excavatus } & \multicolumn{3}{|c|}{ Perionyx sansibaricus } \\
\hline & $\begin{array}{c}\text { At } \\
\text { start }\end{array}$ & $\begin{array}{c}\text { At } \\
\text { end }\end{array}$ & $\begin{array}{c}\text { Production } \\
\text { Rate* }\end{array}$ & $\begin{array}{c}\text { At } \\
\text { start }\end{array}$ & $\begin{array}{c}\text { At } \\
\text { end }\end{array}$ & $\begin{array}{c}\text { Production } \\
\text { Rate* }\end{array}$ & $\begin{array}{c}\text { At } \\
\text { start }\end{array}$ & $\begin{array}{c}\text { At } \\
\text { end }\end{array}$ & $\begin{array}{c}\text { Production } \\
\text { Rate* }\end{array}$ \\
\hline Jbs & 0 & $\begin{array}{c}97.66 \\
\pm \\
4.38^{\mathrm{a}}\end{array}$ & $\begin{array}{c}1.22 \pm \\
0.10^{\mathrm{a}}\end{array}$ & 0 & $\begin{array}{c}106.33 \\
\pm \\
4.46^{\mathrm{a}}\end{array}$ & $\begin{array}{c}1.33 \pm \\
0.14^{\mathrm{a}}\end{array}$ & 0 & $\begin{array}{c}68.0 \pm \\
1.89^{\mathrm{a}}\end{array}$ & $\begin{array}{c}0.83 \pm \\
0.08^{\mathrm{a}}\end{array}$ \\
\hline Fym & 0 & $\begin{array}{c}127.33 \\
\pm \\
3.07^{\mathrm{b}}\end{array}$ & $\begin{array}{l}1.72 \pm \\
0.16^{\mathrm{b}}\end{array}$ & 0 & $\begin{array}{c}143.00 \\
\pm \\
4.33^{\mathrm{b}}\end{array}$ & $\begin{array}{l}1.79 \pm \\
0.17^{\mathrm{b}}\end{array}$ & 0 & $\begin{array}{c}115.3 \\
\pm \\
2.38^{b}\end{array}$ & $\begin{array}{l}1.38 \pm \\
0.13^{\mathrm{b}}\end{array}$ \\
\hline $\mathrm{Kw}+\mathrm{Ll}$ & 0 & $\begin{array}{c}150.67 \\
\pm \\
5.51^{\mathrm{c}}\end{array}$ & $\begin{array}{l}1.88 \pm \\
0.15^{\mathrm{b}}\end{array}$ & 0 & $\begin{array}{c}103.67 \\
\pm \\
3.14^{\mathrm{a}}\end{array}$ & $\begin{array}{l}1.29 \pm \\
0.13^{\mathrm{a}}\end{array}$ & 0 & $\begin{array}{c}141.67 \\
\pm \\
2.33^{\mathrm{c}}\end{array}$ & $\begin{array}{l}1.77 \pm \\
0.14^{\mathrm{c}}\end{array}$ \\
\hline
\end{tabular}

* Cocoons worm ${ }^{-1}$ week $^{-1}$

The mean values followed by different letters are statistically different (ANOVA, Duncan's multipleranged test; $\mathrm{p}<0.05$ )

\section{Cocoon hatchling success and number of hatchlings per cocoon}

Statistically the percent of hatchling success was not different $(\mathrm{P}=0.088)$ among the different species, whereas feeding material or/ substrate type clearly influenced $(\mathrm{P}<0.001)$ the cocoon hatchling success in presently studied earthworms. The cocoons collected from $\mathrm{Kw}+\mathrm{Ll}$ culture showed highest hatchling success (\%) for E. eugeniae (73.19 \%), P. excavatus (74.39\%), and P. sansibaricus $(73.16 \%)$ (Table 5). The cocoons of E. eugeniae, $P$. excavatus and $P$. sansibaricus showed lowest hatchling success, which were collected from Jbs, Fym and Fym culture, respectively (Table 5). The largest numbers of hatchlings $\left(\operatorname{cocoon}^{-1}\right)$ in E. eugeniae were produced on Fym $(1.59 \pm 0.04)$ followed by $\mathrm{Jbs}$, and $\mathrm{Kw}+\mathrm{Ll}$ culture (Table 5). In P. excavatus the largest numbers of hatchlings were obtained in $\mathrm{Kw}+\mathrm{Ll}(1.77 \pm 0.06)$ followed by Fym, and Jbs culture. While, cocoons of $P$. sansibaricus exhibited largest hatchling numbers $\left(\right.$ cocoon $\left.^{-1}\right)$ in Fym $(1.81 \pm 0.10)$ followed by Jbs, and $\mathrm{Kw}+\mathrm{Ll}$ culture. The hatchling numbers per cocoon did not show statistical difference among different species $(\mathrm{P}=0.497)$, whereas, feeding or/ substrate type $(\mathrm{P}<0.001)$ clearly affects the numbers of hatchling per cocoon in presently studied earthworm species (Table 2 ).

Table 5. Cocoon hatchling success and hatchling per cocoon (mean $\pm S E m, n=5)$ in different culture material.

\begin{tabular}{|c|c|c|c|c|c|c|}
\hline \multirow{2}{*}{$\begin{array}{l}\text { Culture } \\
\text { material }\end{array}$} & \multicolumn{2}{|c|}{ Eudrilus eugeniae } & \multicolumn{2}{|c|}{ Perionyx excavatus } & \multicolumn{2}{|c|}{ Perionyx sansibarius } \\
\hline & $\begin{array}{c}\text { Hatchling } \\
\text { success }(\%)\end{array}$ & $\begin{array}{c}\text { Hatchling } \\
\text { cocoon }^{-1}\end{array}$ & $\begin{array}{c}\text { Hatchling } \\
\text { success }(\%)\end{array}$ & $\begin{array}{l}\text { Hatchling } \\
\text { cocoon }^{-1}\end{array}$ & $\begin{array}{c}\text { Hatchling } \\
\text { success }(\%)\end{array}$ & $\begin{array}{c}\text { Hatchling } \\
\text { cocoon }^{-1}\end{array}$ \\
\hline Jbs & $\begin{array}{c}61.62 \pm \\
4.51^{\mathrm{a}}\end{array}$ & $1.55 \pm 0.12^{\mathrm{a}}$ & $56.0 \pm 2.34^{a}$ & $\begin{array}{c}1.14 \pm \\
0.04^{\mathrm{a}}\end{array}$ & $\begin{array}{c}59.19 \pm \\
1.48^{\mathrm{a}}\end{array}$ & $1.30 \pm 0.03^{\mathrm{a}}$ \\
\hline Fym & $\begin{array}{c}66.17 \pm \\
1.53^{\mathrm{a}}\end{array}$ & $1.59 \pm 0.04^{\mathrm{a}}$ & $\begin{array}{c}54.84 \pm \\
0.90^{\mathrm{a}}\end{array}$ & $1.46 \pm 0.14^{\mathrm{b}}$ & $\begin{array}{c}54.59 \pm \\
0.85^{\mathrm{a}}\end{array}$ & $1.81 \pm 0.10^{b}$ \\
\hline $\mathrm{Kw}+\mathrm{Ll}$ & $\begin{array}{c}73.19 \pm \\
2.80^{\mathrm{a}}\end{array}$ & $1.41 \pm 0.04^{\mathrm{a}}$ & $\begin{array}{c}74.34 \pm \\
2.38^{\mathrm{a}}\end{array}$ & $1.77 \pm 0.06^{\mathrm{c}}$ & $\begin{array}{c}77.16 \pm \\
1.15^{\mathrm{b}}\end{array}$ & $1.19 \pm 0.02^{\mathrm{a}}$ \\
\hline
\end{tabular}

The mean values followed by different letters are statistically different (ANOVA, Duncan's multipleranged test; $\mathrm{p}<0.05$ ) 


\section{Discussion}

In this study effort has been made to evaluate the recycling process of some crop residues and growth patterns of $P$. excavatus during vermicomposting process. The substrate material used in this study includes: crop residues of Sorghum vulgare and Pennisetum typhoide amended with sheep manure ( $\mathrm{Jbs}$ ), farmyard manure (Fym), and kitchen waste mixed with leaf litter of Mangifera indica $(\mathrm{Kw}+\mathrm{Ll})$. The substrate combinations namely Jbs, Fym and $\mathrm{Kw}+\mathrm{Ll}$ have different palatability, particle size, microbial structure and chemical composition. Kitchen waste as well as farmyard manure is high quality material with fast decomposition rates, while crop residues are low quality material with slow decomposition rates. All the three composting species showed drastic variations for growth and cocoon production rates among the different culture material. Earthworm showed maximum bio-potential in kitchen waste (discarded vegetables, peel off, green leaves, fermented food etc.) as well as in farmyard manure. According to Fayolle et al. [10] among the different variables necessary for earthworm production, it seems that the type of food is most important. In general the proportion of $\mathrm{N}$ or even $\mathrm{C}$-to- $\mathrm{N}$ ratio of the feeding material appeared to be an important factor for influencing the worms' activity. Cortez and Bouche [6] studied the effect of litter quality on growth patterns of Nicodrilus meridionalis, and reported maximum biomass gain in composted litter treatments. They concluded that this weight increase was possibly related to the C-to-N ratio of the litters, which was lower in composted litters. Hendrikson [15] observed that the growth of earthworm was correlated negatively with $\mathrm{C}$-to- $\mathrm{N}$ ratio of the feeding material. In present study there was also a negative relation between biomass production and $\mathrm{C}-$ to- $\mathrm{N}$ ratio of the culture beddings for E. eugeniae and P. excavatus, which further strongly, supports the above hypothesis. Dramatically biomass production in $P$. sansibaricus did not show the same relation in respect to C-to-N ratio of the culture material.

Overall in present study there was a constant trend of better biomass production in $\mathrm{N}$ rich beddings. More over, the positive correlations recorded between N-content of substrate material and growth rate $\left(\mathrm{mg} \mathrm{worm}^{-1}\right.$ day $\left.^{-1}\right)$ further supports the hypothesis (Table 6).

Table 6. Pearson correlation coefficients between chemical parameters of culture material and biological parameters of different composting species.

\begin{tabular}{cccccc}
\hline Culture material & $\begin{array}{c}\text { Growth } \\
\text { rate }\end{array}$ & $\begin{array}{c}\text { Reproduction } \\
\text { Rate }\end{array}$ & $\begin{array}{c}\text { Hatchling } \\
\text { Succes }\end{array}$ & $\begin{array}{c}\text { Number of } \\
\text { Hatchlings } \\
\text { Cocoon }\end{array}$ & $\begin{array}{c}\text { Total } \\
\text { Population }\end{array}$ \\
\hline E. eugeniae vs. N & $0.868^{* *}$ & 0.470 & $0.679^{*}$ & -0.328 & 0.463 \\
E. eugeniae vs. C-to-N & -0.572 & $-0.932^{* *}$ & -0.554 & 0.161 & -0.305 \\
P. excavatus vs. N & $0.952^{* *}$ & 0.007 & $0.721^{*}$ & -0.082 & $-0.693^{*}$ \\
P. excavatus vs. C-to-N & $-0.986^{* *}$ & -0.400 & -0.358 & -0.161 & -0.417 \\
P. sansibaricus vs. N & $0.727^{*}$ & $0.987^{* *}$ & $0.775^{*}$ & $0.935^{* *}$ & $0.951^{* *}$ \\
P. sansibaricus vs. C- & -0.356 & $-0.946^{* *}$ & -0.464 & $-0.820^{* *}$ & $-0.970^{* *}$ \\
to-N & & & & & \\
\hline
\end{tabular}

$\mathrm{P}<0.05, * * \mathrm{P}<0.01$

The final individual biomass of all studied composting species did not show significant variation between $\mathrm{Kw}+\mathrm{Ll}$ and Fym treatments, even thus these substrates were not differ statistically for their C-to-N ratio $(\mathrm{P}=0.292)$. So here it can be hypothesized that other characters of the substrate such as particle size, palatability, 
microbial composition and presence of special substances were rather more important than its' N-content or C-to-N ratio. In general, different earthworm species are impacted differently by C-to-N ratio of the substrates. Unfortunately, in literature there are no more published reports regarding the impact of substrate or feeding material on growth patterns of the presently studied tropical composting earthworms. Therefore, pilot studies are necessary to establish the optimal C-to-N ratio for a specific earthworm species [27], and a specific feed mixture for specific earthworm for better vermiculture practices. However, on the basis of present results it is concluded that the decomposition efficiency of earthworms in plant derived materials could be retarded due to presence of some chemical substances (e.g. polyphenols). The behaviour of composting earthworm in such kind of wastes must be of a research priority. Comparatively, in present study the earthworm showed least biological potential on Jbs (mainly consist of crop residues), and it could be due to presence of some polyphenols and related substances [2,26] in this culture. Garcia and Fragoso [11] reported influence of feeding source on growth and reproduction performance of Pontoscolex corethrurus and Amynthas cortices. They concluded that despite of $\mathrm{C}-\mathrm{to}-\mathrm{N}$ ratio of the feeding material the concentration of polyphenols and related compounds were more important for controlling earthworm activities.

However, cocoon production rate in presently studied species did not correlate significantly with $\mathrm{N}$-content of the substrate material except to $P$. sansibaricus. Nevertheless, C-to-N ratio showed close negative relationship with cocoon production rate for E.eugeniae and P. sansibaricus (Table 6). It is clear that earthworm exhibited different patterns of cocoon production on presently studied substrates. Studies revealed that $E$. fetida showed drastic variations in cocoon production efficiencies in respect to nature of the waste materials [12,36]. Fayolle et al. [10] pointed out that feeding source played an important role on cocoon production patterns in Dendrobaena veneta. However, the difference in cocoon production patterns in different treatment suggesting a physiological trade-off [32] related to N-limitations [11]. Moreover, the cocoon production behaviour of earthworms' could be interpreted with the chemical, physical and biological properties of waste material. Studies reveal that microbial population of substrate material clearly influences the concentrations of metabolites that consequently affect biological activities of earthworms [10]. Garcia and Fragoso [11] concluded that the presence of some growth-retarding substances in waste material is also important to determine the earthworms' cocoon producing efficiency.

The hatchling success of cocoons collected from different substrate martial also varied statistically. Since, there are no more published reports in literature regarding the effect of substrate quality on cocoon hatchling success. However, it is very hard to define the direct impact of feeding material on such kind of biological activities, so it can be hypothesized that nutrients especially $\mathrm{N}$-content in substrate might be of primary determinant. The significant correlation observed between $\mathrm{N}$-contents of substrate and cocoon hatchling success in E. eugeniae $(\mathrm{r}=0.679, \mathrm{p}<0.05)$, P. excavatus $(\mathrm{r}=0.721$, $\mathrm{p}<0.05)$ and $P$. sansibaricus $(\mathrm{r}=0.775, \mathrm{p}<0.05)$ further strong the proposed hypothesis. Similarly, number of hatchlings $\left(\operatorname{cocoon}^{-1}\right)$ in different substrate material also varied drastically. The broad categories of optimal physico-chemical requirement for composting earthworms on organic waste were confirmed but the nutritional element of their needs remain unclear. There are few other such statements in the literature. The number of hatchlings per cocoon in $P$. sansibaricus was significantly related with $\mathrm{N}$-content $(\mathrm{r}=0.935, \mathrm{p}<0.01)$ as well as with $\mathrm{C}$-to- $\mathrm{N}$ ratio $(\mathrm{r}=-0.820$, 
$p<0.01)$ of the substrate. However, in this study the expected relation between number of hatchlings $\left(\operatorname{cocoon}^{-1}\right.$ ) and substrate $\mathrm{N}$-content and/or C-to-N ratio was not observed for E. eugeniae and P. excavatus species. Therefore, cocoon hatchling success and number of hatchlings per cocoon could be related with the chemical quality of the substrates in which cocoons were laid down. In general, it has been well established that nitrogen content of the culture media affects the cocoon production rate and their further development through influencing the dietary need of the protein for earthworms. It can hypothesize that in nitrogen rich culture media earthworm produce more viable cocoons due to efficient protein supply in their diets. However, in past studies cocoon hatchling success has been studied extensively in terms of their environmental need (temperature, moisture, $\mathrm{pH}$ etc.). In present study effort has been made to evaluate the dietary impact on hatchling success and number of hatchlings per cocoon in composting worms. Clearly evaluating the some degree of optimal chemical composition of substrate material (N-content, $\mathrm{C}$-to- $\mathrm{N}$ ratio, concentration of polyphenols and related compounds) may be beneficial for rapid vermiculture, but more work is still needed to define the hypothesis.

It can be concluded that: better results of biomass as well as reproduction potential of composting earthworm species could be interpreted with the physio-chemical, palatability, and microbial composition of their feeding or substrate materials. Our data demonstrated that quality of the waste material used for vermiculture could drastically influence the biomass production and reproduction performance of composting earthworms. However, tropical composting earthworms: E. eugeniae, P. excavatus, and $P$. sansibaricus had contributed potentially in commercial vermitechnology operations in both tropical and temperate parts of the world. So, using appropriate substrate and/or feeding material for earthworm culture could optimize vermicomposting practices. There are vast opportunities to study the influence of substrate quality interrelating with environmental variables in the field of earthworm biotechnology. Still a great work is required to establish the optimal conditions for culturing of tropical earthworms for sustainable vermiculture operations.

\section{REFERENCES}

[1] Aire, M., Monroy, F., Dominguez, J., Mato, S. (2002): How earthworm density affects microbial biomass and activity in pig manure. - European Journal of Soil Biology 38: 710.

[2] Bostrom, U. (1988): Growth and cocoon production by the earthworm Aporrectodea caliginosa in soil mixed with various plant materials. - Pedobiologia 32: 77-80.

[3] Butt, K. R. (1997): Reproduction and growth of the earthworm Allolobophora chlorotica (Savigny, 1826) in controlled environments. - Pedobiologia 41: 369-374.

[4] Butt, K.R., Fredrickson, J., Morris, R.M. (1992): The intensive production of Lumbricus terrestris L. for soil amelioration. - Soil Biology and Biochemistry 24: 1321-1325.

[5] Cluzeau, D., Fayolle, L. (1989): Croissance et fecondite comparees de Dendrobaena rubida tennis (Eisen, 1874), Eisenia andrei (Bouche, 1972) et Lumbricus rubellus rubellus (Hoffmeister 1843) (Oligochaeta, Lumbricidae) in elevage controle. - Review d'ecolgia et de Biologia du Sole 26: 111-121. 
[6] Cortez, J., Bouche, M. (2001): Decomposition of mediterranean leaf litters by Nicodrilus meridionalis (Lumbricidae) in laboratory and field experiments. - Soil Biology and Biochemistry 33: 2023-2035.

[7] Doube, B.M., Schmidt, O., Killham, K., Correll, R. (1997): Temperature and moisture preference of three earthworm species (Oligochaeta, Lumbricidae). - Pedobiologia 32: 57-64.

[8] Edwards, C.A. (1988): Breakdown of animal, vegetable and industrial wastes by earthworms. - In: Edwards, C. A., Neuhauser E. P. (eds.): Earthworms in Waste and Environmental Management, S.P.B. Academic, The Hague, pp. 21-31.

[9] Edwards, C.A. (1998): The use of earthworms in the breakdown and management of organic wastes. - In: Edwards, C.A. (ed.): Earthworm Ecology. St. Lucie Press, Boca Raton, pp. 327-351.

[10] Fayolle, L., Mitchell, H. Cluzeau, D. 7 Stawiec, J. (1997): Influnence of temperature and food source on the life cycle of the earthworm Dendrobaena veneta (Oligochaeta). - Soil Biology and Biochemistry 29: 747-750.

[11] Garcia, J.M., Fragoso, C. (2002): Influence of different food substrates on growth and reproduction of two tropical earthworm species (Pontoscolex corethrurus and Amynthas corticis). - Pedobiologia 47: 754-763.

[12] Garg, V. K., Kaushik, P. (2005): Vermistabilization of textile mill sludge spiked with poultry droppings by an epigeic earthworm Eisenia fetida. - Bioresource Technology 96: 1063-1071.

[13] Hallatt, L., Viljoen, S. A., Reinecke, A.J. (1992): Moisture requirements in the life cycle of Perionyx excavatus (Oligochaeta). - Soil Biology and Biochemistry 24: 1333-1340.

[14] Hartenstein, R. (1983): Assimilation by the earthworm Eisenia fetida. - In: Satchell, J.E. (ed.): Earthworm Ecology from Darwin to Vermiculture, Chapmann and Hall, London, pp. 297-308.

[15] Hendrickson, N. B. (1990): Leaf litter selection by detritivorous and geophagous earthworms. - Biology and Fertility of Soils 10: 77-21.

[16] Kale, R. D., Bano, K. (1991): Time and space relative population growth of Eudrilus eugeniae. - In: Veeresh, G. K., Rajagopal, D., Virakamath, C.A. (eds.): Advances in Management and Conservation of Soil Fauna, Oxford and IBH, New Delhi, pp. 657-664.

[17] Kaplan, D. L., Hartenstein, R., Neuhauser, E.F., Malecki, M.R. (1980): Physiochemical requirements in the environment of the earthworm Eisenia foetida. - Soil Biology and Biochemistry 12: 347-352.

[18] Kaushik, P., Garg, V.K. (2003): Vermicomposting of mixed solid textile mill sludge and cow dung with the epigeic earthworm Eisenia fetida. - Bioresource Technology 90: 311-316.

[19] Kavian, M.F., Ghatnekar, S.D., Kulkarni, P.R. (1998): Conservation of coir pith in to value Added Biofertilizer using Lumbaricus rubellus. - Indian Journal Environmental Protection 18: 354-358.

[20] Loehr, R. C. Neuhauser, E.F., Malecki, M.R. (1985): Factors affecting the vermistabilization process, Water Research 19: 1311-1317.

[21] Lofs-Holmines, A. (1986): Occurrence of eleven earthworm species (Lumbricidae) in permanent pastures in relation to soil-pH. - Swedish Journal of Agriculture Research 16: 161-165.

[22] Loh, T.C., Lee, Y.C., Liang, J.B., Tan, D. (2005): Vermicomposting of cattle and goat manures by Eisenia fetida and their growth and reproduction performance. Bioresource Technology 96: 111-114. 
[23] Lowe, C. N., Butt, K.R. (2002): Growth of hatchling earthworms in the presence of the adults: Interaction in laboratory culture. - Biology and Fertility of Soils 35:204-209.

[24] Lowe, C.N., Butt, K. R. (2005): Culture techniques for soil dwelling earthworms: A review. - Pedobiologia 49: 401-413.

[25] Maboeta, M.S., Rensbugr, L. van (2003): Vermicomposting of industrially produced woodchips and sewage sludge utilizing Eisenia fetida. - Ecotoxicology and Environmental Safety 56: 265-270.

[26] Martin, A., Lavelle, P. (1992): Effect of soil organic matter quality on its assimilation by Millsonia anomala, a tropical geophagous earthworm. - Soil Biology and Biochemistry 24: 1535-1538.

[27] Ndegwa, P. M., Thompson, A (2000): Effects of C-to-N ratio on vermicomposting of biosolids. - Bioresource Technology 75: 7-12.

[28] Reinecke, A. J., Kriel, J.R. (1981): Influence of temperature on the reproduction of the earthworm Eisenia foetida (Oligochaeta). - South African Journal of Zoology 16: 96-100.

[29] Reinecke, A.J., Venter, J. M. (1987): Moisture preference, growth and reproduction of the composting worm Eisenia foetida (Oligochaeta). - Biology and Fertility of Soils 3: 135141

[30] Rhee, U. (1992): Influence of population densities on growth and reproduction of the earthworm Eisenia andrei on pig manure. - Soil Biology and Biochemistry 24: 13271331

[31] Singh, N.B., Khare, A.K., Bhargava, D.S., Bhattacharya, S. (2005): Effect of initial substrate $\mathrm{pH}$ on vermicomposting using Perionyx excavatus (Perrier, 1872). - Applied Ecology and Environmental Research 4: 85-97.

[32] Strearns, S.C. (1992): The evolution of life histories. - Oxford University press, New York, United States, pp. 72-90.

[33] Suthar, S.S. (2002): Earthworm Resources and Their Utilization in Vermitechnology in Desert Region of Rajasthan. - Ph. D. Thesis, J.N.V. University, Jodhpur, India.

[34] Suthar, S. (2006): Vermiculture: taknique avum upyogita. - Scientific Publishers Jodhpur, India.

[35] Suthar, S. (2006): Potential utilization of guar gum industrial waste in vermicompost production. - Bioresource Technology (In press)

[36] Suthar, S. S., Watts, J. Sandhu, M. Rana, S. Kanwal, A. Gupta, D., Meena, M.S. (2005): Vermicomposting of kitchen waste by using Eisenia fetida (Savigny). Asian Journal of Microbiology Biotechnology and Environmental Science 7: 541544.

[37] Viljoen, S. A., Reinecke, A.J. (1992): The temperature requirement of the epigeic earthworm species Eudrilus eugeniae (Oligochaeta) - A laboratory study. - Soil Biology and Biochemistry 24: 1345-1350.

[38] Vinceslas-Akpa, M., Loquet, M. (1997): Organic matter transformation in lignocellulosic waste products composted or vermicomposted (Eisenia fetida andrei): chemical analysis and 13C CPMAS NMR spectroscopy. - Soil Biology and Biochemistry 29: 751-758. 